\title{
MUTATION ANALYSIS OF CACNA1A AND ATP1A2 GENES IN BRAZILIAN FHM FAMILIES
}

\author{
Luciana R. Lopes', Mario Fernando Prieto Peres², Kaate R.J. Vanmolkot ${ }^{3}$, \\ Patrícia R. Tobo ${ }^{1}$, Eliova Zukerman ${ }^{4}$, Rune R. Frants ${ }^{5}$, \\ Arn M.J.M. van den Maagdenberg ${ }^{5}$, Carlos Alberto Moreira-Filho ${ }^{6}$
}

\begin{abstract}
Familial hemiplegic migraine (FHM) is a rare autosomal dominant form of migraine with aura. This disease has been associated with missense mutations in the CACNA1A and ATP1A2 genes. The aim of this study was to identify whether CACNA1A and ATP1A2 are or not related to Brazilian FHM. Here we screned four Brazilian FHM families (total of 26 individuals - 13 affected and 13 asymptomatic or normal) for mutations in both genes. We found an amino acid change in a member of family FHM-D(Arg2206Gly). However since this alteration is not present in all affected individuals and is present in one asymptomatic individual it should be considered a polymorphism. Further studies with additional families will be necessa ry to reveal the importance of both CACNA1A and ATP1A2 genes on the pathogeneses of FHM in Brazil and to test the third gene (SCN1A) in these FHM families.
\end{abstract}

KEY WORDS: familial hemiplegic migraine, CACNA1A, ATP1A2, SCN1a, gene, mutation.

\begin{abstract}
Análise de mutações dos genes CACNA1A e ATP1A2 em famílias brasileiras afetadas por enxaqueca hemiplégica familial

RESUMO - A enxaqueca hemiplégica familial (EHF) é uma forma rara de enxaqueca com aura e apresenta herança autossômica dominante. Esta doença está associada com mutações do tipo missense nos genes CACNA1A e ATP1A2. O objetivo deste estudo foi identificar se os genes CACNA1A e ATP1A2 estão ou não relacionados com a enxaqueca hemiplégica familial em famílias brasileiras. Os genes citados acima foram analisados em quatro famílias brasileiras (total de 26 indivíduos - 13 afetados e 13 assintomáticos ou normais) e uma troca de aminoácido em um membro da família FHM-D (Arg2206Gly) foi observada. Porém, esta alteração não foi identificada em todos os indivíduos afetados e está presente em um indivíduo assintomático, devendo, portanto, ser considerada um polimorfismo. Estudos adicionais nas famílias já estudadas e em outras famílias brasileiras afetadas por enxaqueca hemiplégica familial serão necessários para esclarecer a importância dos genes CACNA1A e ATP1A2 na patogênese da EHF no Brasil, bem como para testar o terceiro gene $(\mathrm{SCN} 1 \mathrm{~A})$ relacionado à EHF.
\end{abstract}

PALAVRAS-CHAVE: enxaqueca hemiplégica familial, gene CACNA1A, gene ATP1A2, gene SCN1a, mutação.

Migraine is a common neurological disorder that affects up to $18 \%$ of the general population. Familial hemiplegic migraine (FHM) is a rare autosomal dominantly inherited subtype of migraine with aura. In FHM the aura usually consist of a phase with hemiparesis accompanied by typical aura symptoms, including visual, sensory or speech disturbances, followed by a headache phase ${ }^{1,2}$. Roughly half of the FHM families are linked to chromosome 19p13 (FHM1) other FHM families are linked to chromosome 1q23 (FHM2) ${ }^{4-10}$. Recently, a third FHM locus (FHM3) was identified located on chromosome $2 q 24$. Still families are not linked to either of these loci ${ }^{11}$.

The neuronal FHM1 gene CACNA1A encodes the pore-forming subunit of voltage-gated $\mathrm{Ca}^{2+}$-channel $1^{3,12,13}$. Virtually all FHM families with cerebellar signs were shown to have mutations in CACNA1A in all families studied ${ }^{13-18}$ except one study that showed an ATP1A2 in a FHM family mutation with cere be 1 lar signs ${ }^{8}$. Pure hemiplegic migraine has been associated with mutations in CACNA1A in many families $^{19,20}$. The causative gene for the FHM2 locus on

${ }^{1} \mathrm{MSc}$, Instituto de Ensino e Pesquisa, Hospital Israelita Albert Einstein, São Paulo SP, Brazil (HIAE); ${ }^{2} \mathrm{MD}, \mathrm{PhD}, \mathrm{HIAE} ;{ }^{3} \mathrm{MSc}$, Leiden University Medical Center, Leiden, The Netherlands (LUMC); ${ }^{4} \mathrm{MD}, \mathrm{HIAE} ;{ }^{5} \mathrm{PhD}$, LUMC; ${ }^{6} \mathrm{PhD}, \mathrm{HIAE}$, Departamento de Imunologia do Instituto de Ciências Biomédicas da Universidade de São Paulo, Brazil.

Received 30 January 2006, received in final form 3 April 2006. Accepted 10 May 2006.

Dra. Luciana R. Lopes - Instituto de Ensino e Pesquisa, Hospital Israelita Albert Einstein - Avenida Albert Einstein 627 - 05651-901 São Paulo SP - Brasil. E-mail: lucianarl@einstein.br 


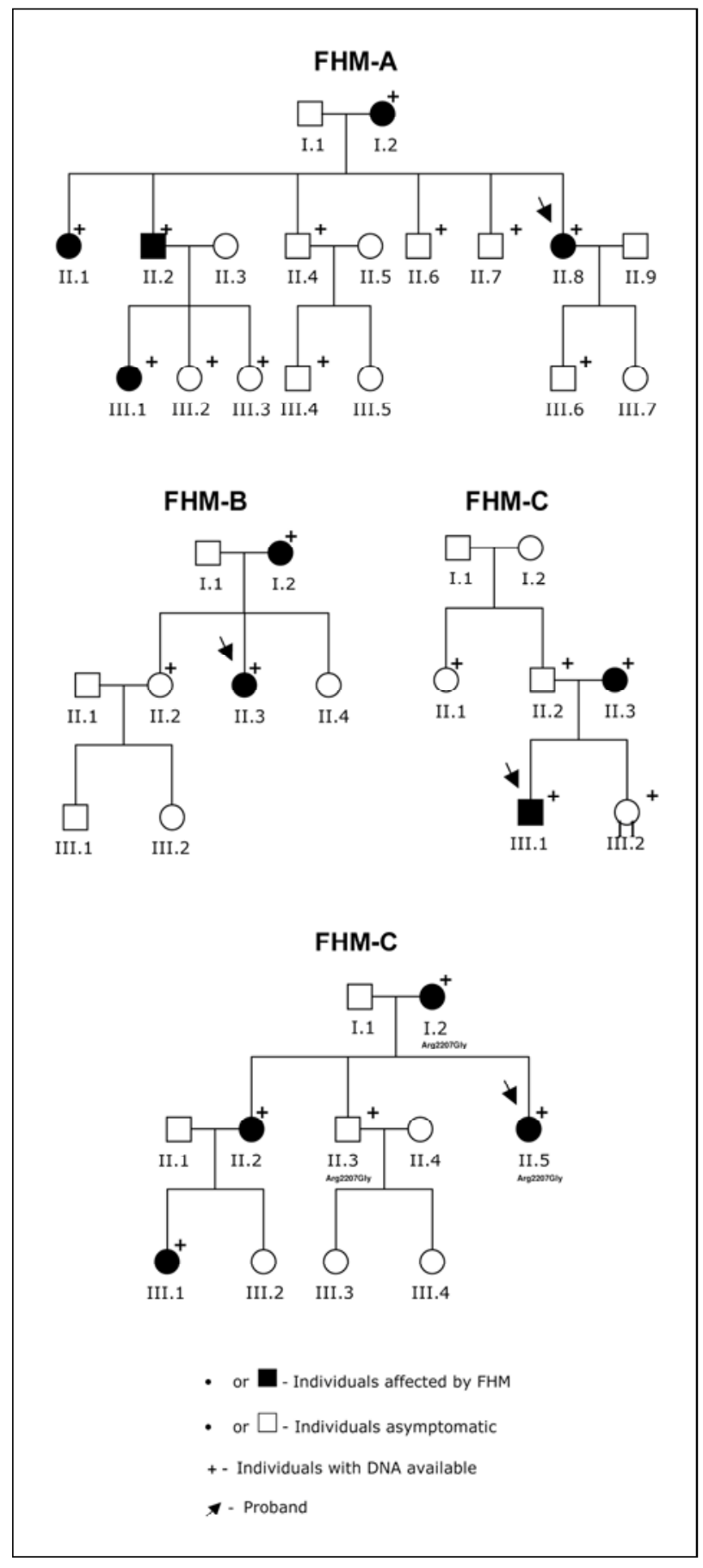

Fig 1. Pedigrees of Brazilian FHM families.

ch romosome 1q23 was identified in 2003. This gene, ATP1A2, encodes the alpha-2 catalytic subunit of a sodium-potassium-ATPases ${ }^{21}$. Several additional missense FHM mutations in the ATP1A2 gene have been identified since ${ }^{7-10}$. SCN1A is the causative gene in the recently discovered FHM3 locus. SCN1A encodes the pore-forming subunit of neural-voltage-gated $\left(\mathrm{Na}_{v} 1.1\right)$ sodium channels ${ }^{11}$. A missense GIn1489Lys mutation was identified in three German families with common ancestry. The functional analyses re- vealed that mutation causes a two-fold to four-fold accelerated recovery from fast inactivation.

In this report, we screened for mutations in the CACNA1A and ATP1A2 genes in four Brazilian FHM families (Fig 1).

\section{METHOD}

Subjects - The present study was approved by the local Ethical Commite in Research (Albert Einstein Hospital - São Paulo / Brazil) in May/2003. All subjects provided written informed consent, as required by appropriate local (and national) committees on the protection of research subjects, and were interviewed and examined by one of the neurologist of the Albert Einstein Hospital (Peres, MFP; Zuk e rman, E). Diagnostic criteria of the International Headache Society were used to define familial hemiplegic migraine (IHS, 2004). Four Brazilian FHM families without cerebellar signs were analyzed (FHM-A, FHM-B, FHM-C and FHM-D - Fig 1) and selected from June/2003 to December/2004.

Clinical features - A total of 26 individuals (16 females and 10 males) were selected, where 13 were affected and 13 were asymptomatic or normal. The middle age was 29 years. All four probands have other family members with episodes of hemiplegia (Table). The age of onset of hemiplegics episodes varied from 3 to 30 years, and the typical duration of episodes varied from minutes to days.

Genomic DNA samples - Blood samples of all patients we re collected and genomic DNA was isolated from leukocytes as described by ${ }^{22}$.

Mutation screening - We screened the probands from families FHM-A, FHM-B, FHM-C and FHM-D for mutations in the CACNA1A (47 exons) and ATP1A2 (23 exons) genes. Mutation analysis was performed by direct sequencing of all exons and flanking introns.

\section{RESULTS}

Mutation analysis of the CACNA1A and ATP1A2 genes in probands of four Brazilian FHM families revealed several polymorphisms, but no mutations were identified in either gene. In the individual FHM-D II.5 (Fig 2) an amino acid change was identified substituting a glycine for an arginine (Arg2206Gly) in exon 46 of the CACNA1A gene (Fig 2). Her mother (FHM-D I.2), affected by FHM, presented the same alteration, but her brother (FHM-D II-3), an asymptomatic individual, has the same aminoacid change. This result show this alteration is a polymorphism not related to the disease. No other amino acids changes were identified in the CACNA1A or ATP1A2 genes of the FHM probands. There remain always the possibility of deletions and promoter mutations that remain undetected with direct sequencing. 
Table. Clinical signs of Brazilian FHM index patients.

\begin{tabular}{|c|c|c|c|c|c|c|c|c|}
\hline $\begin{array}{l}\text { Patient } \\
\text { Identification }\end{array}$ & Sex & $\begin{array}{c}\text { Age } \\
\text { (years) }\end{array}$ & $\begin{array}{l}\text { Age at } \\
\text { onset }\end{array}$ & Aura & Hemiplegia & $\begin{array}{l}\text { Photofobia } \\
\text { Phonofobia }\end{array}$ & Ataxia & $\begin{array}{l}\text { Familial } \\
\text { history }\end{array}$ \\
\hline FHMA-I.2 & $\mathrm{F}$ & 63 & 15 & Y & Y & Y & $N$ & Y \\
\hline FHMA-II11 & $\mathrm{F}$ & 43 & 3 & Y & Y & Y & $\mathrm{N}$ & Y \\
\hline FHMA-II12 & M & 38 & 8 & Y & Y & Y & $\mathrm{N}$ & Y \\
\hline FHMA-II18 & $\mathrm{F}$ & 33 & 8 & Y & Y & Y & $\mathrm{N}$ & $Y$ \\
\hline FHMA-III. 1 & $\mathrm{~F}$ & 21 & 14 & Y & Y & Y & $N$ & $Y$ \\
\hline FHMB-II.2 & $\mathrm{F}$ & 60 & 30 & Y & Y & Y & $N$ & Y \\
\hline FHMB-II.3 & $\mathrm{F}$ & 31 & 16 & Y & Y & Y & $\mathrm{N}$ & Y \\
\hline FHMC-I.1 & $\mathrm{F}$ & 53 & 10 & Y & Y & Y & $\mathrm{N}$ & Y \\
\hline FHMC-II. 1 & M & 23 & 7 & Y & Y & Y & $\mathrm{N}$ & Y \\
\hline FHMD-I.2 & $\mathrm{F}$ & 60 & 10 & Y & Y & Y & $\mathrm{N}$ & $Y$ \\
\hline FHMD-II.1 & $\mathrm{F}$ & 40 & 12 & Y & Y & Y & $\mathrm{N}$ & Y \\
\hline FHMD-!!.5 & $\mathrm{F}$ & 38 & 15 & Y & Y & Y & $\mathrm{N}$ & Y \\
\hline FHMD-III. 1 & $\mathrm{~F}$ & 10 & 7 & Y & Y & Y & $\mathrm{N}$ & Y \\
\hline
\end{tabular}

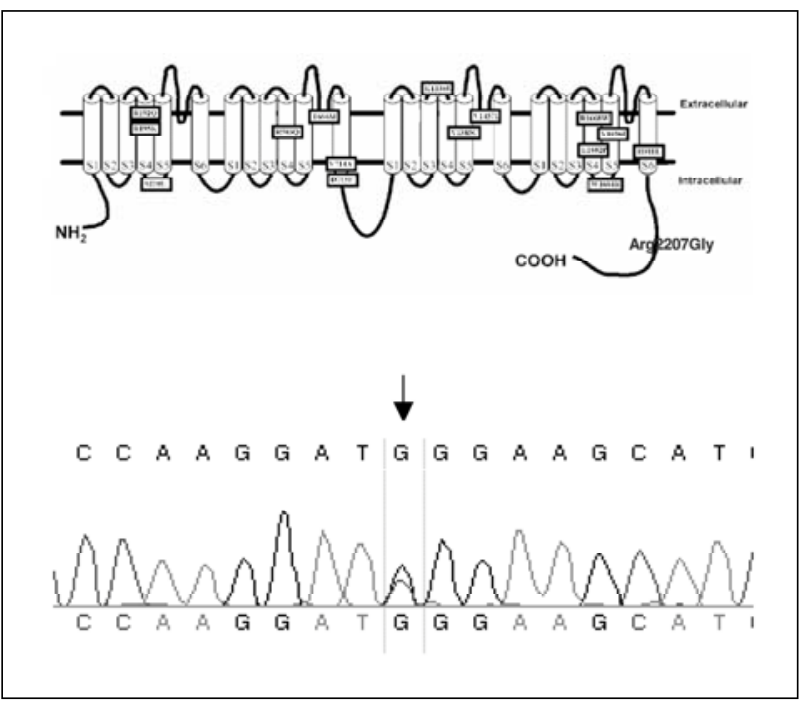

Fig 2. Sequencing alteration Arg2206Gly - FHM-D II.3.

\section{DISCUSSION}

No mutations were identified in CACNA1A or ATP1A2 genes of probands of four Brazilian FHM families, only one novel amino acid change (Arg2206 Gly) that is, probably, a polymorphism. This amino acid change was present in two affected (FHM-D I.2 and FHM-D II.5) and one asymptomatic individual (FHM-D II.3), excluding that this variation is causative in this family. The location of this alteration occurre $d$ in an important part of the gene (cytoplasmatic domain), so functional studies could be important to reveal whether this alteration is or not related to the phenotype in this patient (FHMD-II.5). The present functional tests are designed to look at the currents of the channel. For this, the mutations need to be in the transmembrane domains or in short loops ( $P$ loops). A mutation in the cytoplasmatic domain might be located in a binding domain of the associated, regulatory proteins. Test whether the mutation affects binding of these proteins has never been tried for a pathogenic mutation.

This is the first report of Brazilian FHM families and these data suggest that maybe both genes are not involved in these Brazilian FHM families. None of the patients in our FHM families had interictal ata$\mathrm{xia}$, nystagmus or seizures.

Future studies will be important to understand the role of both genes in our population. Of course it is possible that other Brazilian FHM families may have mutations on the CACNA1A or ATP1A2 genes, especially FHM families presenting with ataxia and/or seizure. Besides, the investigation of the third FHM gene (SCN1A) will be performed to investigate the role of this gene in our FHM families.

In conclusion, in our four FHM families no mutations in either FHM gene were identified and we have no evidence for involvement of these genes in these families. This may be an indication that SCN1A gene is causing FHM in these families. 


\section{REFERENCES}

1. Launer LJ, Terwindt GM, Ferrari MD. The prevalence and characteristics of migraine in a populational-based cohort: the GEM study. Neurology 1999;53:537-542.

2. Stewart W, Breslau N, Keck PE Jr. Comorbidity of migraine and panic disorder. Neurology 1994;44(Suppl):S23-S27.

3. Joutel A, Bousser M-G, Biousse V, et al. A gene for familial hemiplegic migraine maps to chromosome 19. Nat Genet 1993;5:40-45.

4. Ducros A, Joutel A, Vahedi K, et al. Mapping of a second locus for familial hemiplegic migraine to 1q21-q23 and evidence of further heterogeneity. Ann Neurol 1997;42:885-890.

5. Gardner K, Barmada MM, Ptacek LJ, Hoffman EP. A new locus for hemiplegic migraine maps to chromosome 1q31. Neurology 1997; 49:1231-1238.

6. Marconi R, De Fusco M, Aridon P, et al. Familial hemiplegic migraine type 2 is linked to $0,9 \mathrm{Mb}$ region on chromosome 1q23. Ann Neurol 2003;53:376-381.

7. Vanmolkot KR, Kors EE, Hottenga JJ, et al. Novel mutations in the $\mathrm{Na}+/ \mathrm{K}+$-ATPase pump gene ATP1A2 associated with familial hemiplegic migraine and benign familial neonatal convulsion. Ann Neurol 2003; 54:360-366.

8. Spadaro M, Ursu S, Lehmann-Horn F, et al. A G301R Na+/K+-ATPase mutation causes familial hemiplegic migraine type 2 with cerebellar signs. Neurogenetics 2004;5:177-185.

9. Kaunisto MA, Harno H, Vanmolkot KR, et al. A novel missense ATP1A2 mutation in a Finnish family with familial hemiplegic migraine type 2. Neurogenetics 2004;5:141-146.

10. Jurkat-Rott K, Freilinger T, Dreier JP, et al. Variability of familial hemiplegic migraine with novel A1A2 Na+/K+-ATPase variants. Neurology 2004;62:1857-1861.

11. Dichgans $M$, Freilinger T, Eckstein G, et al. Mutation in the neuronal voltage-gated sodium channel SCN1A in familial hemiplegic migraine. Published online June 28, 2005. www.thelancet.com
12. Joutel A, Ducros A, Vahedi K, et al. Genetic heretogeneity of familial hemiplegic migraine. Am J Hum Genet 1994;55:1166-1172.

13. Ophoff RA, Terwindt GM, Ve rgouwe MN, et al. Familial hemiplegic migraine and episodic ataxia type- 2 are caused by mutations in the $\mathrm{Ca}(2+)$ channel gene CACNL1A4. Cell 1996;87:543-552.

14. Terwindt GM, Ophoff RA, Haan J, Sandkuijl LA, Frants RR, Ferrari MD. Migraine, ataxia and epilepsy: a challenging spectrum of genetically determined calcium channelopathies. Dutch Migraine Genetics Research Group. Eur J Hum Genet 1998;6:297-307.

15. Ducros A, Denier C, Joutel A, et al. Recurrence of the T666M calcium channel CACNA1A gene mutation in familial hemiplegic migraine with progressive cerebellar ataxia. Am J Hum Genet 1999;64:89-98.

16. Battistini S, Stenirri S, Piatti M, et al. A new CACNA1A gene mutation in acetazolamide-responsive familial hemiplegic migraine and ataxia. Neurology 1999;53:38-43.

17. Friend KL, Crimmins D, Phan TG, et al. Detection of a novel missense mutation and second recurrent mutation in the CACNA1A gene in individuals with EA-2 and FHM. Hum Genet 1999;105:261-265.

18. Vahedi K, Denier C, Ducros A, et al. CACNA1A gene de novo mutation causing hemiplegic migraine, come and cerebellar atrophy. Neurology 2000;55:1040-1042.

19. Kors EE, Vanmolkot KR, Haan J, et al. Alternating hemiplegia of childhood: mutations in the second familial hemiplegic migraine gene ATP1A2. Neuropediatrics 2004;35:293:296.

20. Carrera P, Piatti M, Stenirri S, et al. Genetic heterogeneity in Italian families with familial hemiplegic migraine. Neurology 1999;53:26-33.

21. De Fusco M, Marconi R, Silvestri L, et al. Haploinsufficiency of ATP1A2 enconding the $\mathrm{Na}+/ \mathrm{K}+$ pump alpha2 subunit associated with familial hemiplegic migraine type 2. Nat Genet 2003;33:192-196.

22. Miller SA, Dykes DD, Polesky HF. A simple salting out procedure for extracting DNA from human nucleated cells. Nucleic Acids Res 1988;16:1215. 